\title{
Application of traffic impact studies as part of the EIA process: a case study as applied to the extension of a mineral processing plant
}

\author{
I. M. Schoeman \\ School for Computer, Statistical and Mathematical Sciences, \\ North West University, Potchefstroom Campus, South Africa
}

\begin{abstract}
The publication of the National Environmental Management Act (NEMA) (Act 107 of 1998) in South Africa introduced a new approach to and the role of environmental and transportation planning in development. NEMA provides the framework for co-operative environmental governance and promotes the application of environmental assessment and management tools to ensure integrated environmental management of activities. The intention of NEMA was formalized through the publication of the EIA Regulations (2006).

On 3 August, 2010 the revised NEMA EIA Regulations were promulgated that included changes in the process, procedure and listing of activities. With the proclamation of the EIA Regulations the need to determine the impact of traffic (TIS or TIA) within a development site (activity in terms of environmental authorization) became an optional addition as a specialist report. The paper includes the methodology and lessons learnt in the process (case study) of traffic impact study (or assessment) (TIS/TIA) formulation. This intricate interface between the environmental impact assessment (EIA) and TIS/TIA processes and formulation are being investigated based on content, application and implementation principles. The paper is concluded with recommendations as how to mitigate the impact of traffic within a development site in context to the EIA process for activity authorization.

Keywords: traffic impact assessment, transportation planning, environmental assessment, sustainable development, environmental mitigation measures.
\end{abstract}




\section{Introduction}

South Africa was slow to develop and institute formal procedures for environmental assessment. It was only with the enactment of the Environment Conservation Act [1] that provision was made to determine environmental policy to guide decision-making and to prepare environmental impact reports [2]. The publication of a document entitled 'Integrated Environmental Management (IEM) in South Africa' [3] introduced the concept of environmental management. The term IEM was chosen to indicate a general approach that integrates environmental considerations across all stages of the planning and development cycle and would be applicable to policies, programs, plans and projects [2].

The publication of the National Environmental Management Act (NEMA) [4] introduced the new approach to and role of environment in development. NEMA provides a framework for co-operative environmental governance in South Africa and promotes the application of environmental assessment and management tools to ensure integrated environmental management of activities [5]. The intention of NEMA was formalized through publication of the EIA Regulations (2006) [6]. On 3 August, 2010 the revised NEMA EIA Regulations [7] were promulgated that included changes in the listing of activities.

The alignment between the application of the EIA process and the need for traffic impact studies or assessment (TIS/TIA) is being applied in South Africa based on the nature and extend of such activity and the judgement of specialists involved in environmental authorization processes. There exists thus no formal guiding policy or legal requirements enforcing TIS/TIA formulation other than as a requirement for a specialist report in terms of the environmental authorization process. The purpose of this paper is to highlight the importance of a TIS/TIA to inform environmental authorization processes and how to implement applicable mitigation measures to support sustainable development.

\section{Research methodology}

The research methodology applied includes the following focuses: policy, legislation and literature considerations; case study content, approach and application; reporting on case study main results from a TIS/TIA perspective and EIA and TIS/TIA mitigation measures, recommendations and implementation.

\section{Policy, legislative and literature considerations}

\subsection{Policy overview}

Various tools exist in order to guide environmental management and include Environmental Management Frameworks (EMFs); Strategic Environmental Assessments (SEAs) and Cumulative Environmental Assessments (CEAs) that informs the formulation of EIA. TIS/TIAs on the other hand, is being informed by Integrated Development Plans (IDPs), Spatial Development Frameworks (SDFs); Land Use Management Plans (LUMPs); Land Use Schemes (LUS) (statutory planning procedures); Integrated Transport Plans (ITPs); Public 
Transport Plans (PTPs); Transport Infrastructure Plans (PIPs) and Route Alignment Assessment (RAA).

From the diversity of plans as illustrated above the need to integrate decision making within a trans-disciplinary approach can clearly be deduced. However, in terms of the core policies driving the content of the various plans, there are limited measures in place to align and integrate the plans as to promote sustainable development.

\subsection{Legislative overview}

The formulation of EIAs is prescribed in the National Environmental Management Act [4] and its Regulations (2010) [7]. In terms of the focus of this paper it should be noted that the regulations include certain listings applicable to activities requiring environmental authorization prior to commencement of development.

The EIA is a pro-active and systematic process where potential environmental impacts both positive and negative associated with certain activities are assessed, investigated and reported on. The process contributes to giving effect to the objectives of integrated environmental management (IEM) as decision makers are informed of the desirability of such activities and on the conditions which authorization of the activity should be subject to, where relevant. This in part explains the interface between the concepts of the EIA and the TIS/TIA within the focus of this research as applied to the study area.

In terms of Regulation 32 of the EIA Regulations (2010) [7] provision is made for the compilation of specialist reports that includes the formulation of TIS/TIAs. In context to transportation planning, inclusive of development and operational activities, is being prescribed and guided in the National Land Transport Act (5 of 2009) [8] and its promulgated regulations [9]. No provision is included guiding the need to formulate TIS/TIAs.

The formulation of TIS/TIAs in practice is being guided in terms of the contents of an ITP and the LUS in terms of statutory planning processes within a specific institutional entity. Research undertaken for the compilation of this paper, indicated that a Manual for Traffic Impact Studies were compiled by the Department of Transport in 1995 [10]. From the research it also became evident that a draft manual on traffic impact and site assessments was prepared by the Committee of Transport Officials (COTO) during 2008 [11]. This document includes most of the principles as contained in the Manual of 1995 [10] but was never formally published.

\subsection{Literature overview}

For the literature related to EIA formulation in South Africa the reader is referred to the content of NEMA [4] and the EIA Regulations [7]. The literature is dealt with in the Department of Environment and Tourism (DEAT) in terms of the Integrated Environmental Management Information Series Guidelines (refer to [12-16]). 
For the focus of this paper the literature overview will be based on the content of TIS/TIAs as applicable within international practice. Table 1 shows a concise summary of three recognised formats related to the content of TIS or TIAs.

Table 1: $\quad$ Generic content of TIS/TIAs based on international practice.

\begin{tabular}{|c|c|c|}
\hline $\begin{array}{c}\text { Asia Society for Transport } \\
\text { Studies [17] }\end{array}$ & $\begin{array}{l}\text { Alberta Traffic Impact } \\
\text { Assessment Guideline [18] }\end{array}$ & $\begin{array}{l}\text { Cape Cod Commission } \\
\text { Guidelines for Transportation } \\
\text { Impact Assessment [19] }\end{array}$ \\
\hline $\begin{array}{l}\text { Current practices in the } \\
\text { Philippines: } \\
\text { - Definition of the impact area. } \\
\text { - Characterization of baseline } \\
\text { traffic. } \\
\text { - Estimation of traffic } \\
\text { generation attributed to the } \\
\text { project. } \\
\text { - Formulation of traffic } \\
\text { management plan. } \\
\text { - Access points and routing } \\
\text { analysis. } \\
\text { - Parking requirement } \\
\text { analysis. } \\
\text { - Formulation of } \\
\text { implementation mechanisms } \\
\text { for recommended counter } \\
\text { measure. }\end{array}$ & 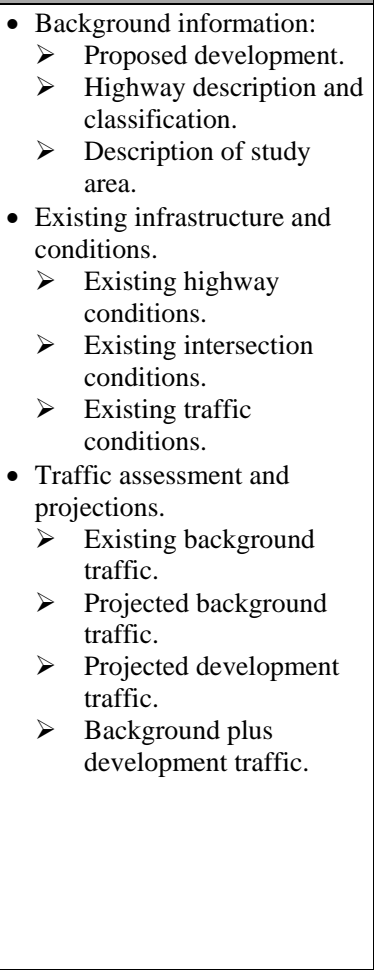 & $\begin{array}{l}\text { Project introduction } \\
>\text { Project description. } \\
\text { Locus map-to set } \\
\text { context regionally. } \\
\text { Site access and context } \\
\text { map. } \\
\text { - Eite plan. } \\
>\text { Roisting conditions: } \\
\text { Road network. } \\
\text { Traffic volumes. } \\
\text { Pedestrian and bicycle } \\
\text { counts. } \\
\text { Air quality analysis. } \\
\text { Crash history and } \\
\text { analysis. } \\
\text { Capacity and Level of } \\
\text { Trip generation: } \\
\text { Traffic assessment } \\
\text { Alternative trip } \\
\text { generation. } \\
\text { Land use interactions. } \\
\text { Impact of multi-use } \\
\text { developments. } \\
\text { Impact of growth and } \\
\text { activity centres. } \\
\text { Estimation of heavy } \\
\text { vehicle traffic. } \\
\text { Adjustments to trip } \\
\text { generation. }\end{array}$ \\
\hline $\begin{array}{l}\text { Approach in case of new } \\
\text { development: } \\
\text { - Estimation of traffic } \\
\text { generation with and without } \\
\text { the project. } \\
\text { - Estimated traffic volumes at } \\
\text { approach routes and critical } \\
\text { intersections with and } \\
\text { without the project. } \\
\text { - Identification of locations of } \\
\text { potential traffic congestion } \\
\text { due to the project. } \\
\text { - Recommendation of } \\
\text { remedial measures to } \\
\text { overcome potential traffic } \\
\text { problems with the project. }\end{array}$ & $\begin{aligned} \text { Analysis: } \\
\text { Capacity analysis. } \\
\text { Traffic signalization } \\
\text { analysis. } \\
>\quad \text { Illumination warrants } \\
\text { analysis. } \\
>\quad \text { Pedestrian warrant } \\
\text { analysis. } \\
>\text { Operational analysis. }\end{aligned}$ & $\begin{array}{l}\text { Trip distribution: } \\
\text { Distribution patterns. } \\
\text { Trip generation } \\
\text { assumptions and } \\
\text { qualifications. } \\
\text { - Future conditions: } \\
>\quad \text { Traffic volumes for 'no- } \\
\text { build' or 'build' } \\
\text { scenarios. } \\
>\quad \text { Current projects. } \\
>\quad \text { Capacity and LOS } \\
\\
\text { analysis } \\
>\quad \text { Signal warrant analysis. } \\
\text { Summary: LOS } \\
\text { performance indicators } \\
\text { for development } \\
\text { scenarios. }\end{array}$ \\
\hline
\end{tabular}


Table 1: $\quad$ Continued.

\begin{tabular}{|c|c|c|}
\hline $\begin{array}{c}\text { Asia Society for Transport } \\
\text { Studies [17] }\end{array}$ & $\begin{array}{c}\text { Alberta Traffic Impact } \\
\text { Assessment Guideline [18] }\end{array}$ & $\begin{array}{l}\text { Cape Cod Commission } \\
\text { Guidelines for Transportation } \\
\text { Impact Assessment [19] }\end{array}$ \\
\hline $\begin{array}{l}\text { Other tasks: } \\
\text { - Inventory of the physical } \\
\text { conditions of the study area. } \\
\text { - Conduct primary and } \\
\text { secondary traffic count data } \\
\text { for roads in the project and } \\
\text { environs. } \\
\text { - Projection of the traffic } \\
\text { generated/attracted by the } \\
\text { development. } \\
\text { - Estimation of the service } \\
\text { levels of roads and } \\
\text { intersections. } \\
\text { - Evaluation of impacts for } \\
\text { future traffic. }\end{array}$ & $\begin{array}{l}\text { - Conclusions and } \\
\text { recommendations: } \\
>\quad \text { Required intersection } \\
\text { improvements. } \\
>\text { Pedestrian mitigation. } \\
>\text { Illumination. } \\
>\text { Signalization. } \\
>\text { Right of way } \\
\text { requirements. }\end{array}$ & $\begin{array}{l}\text { - Mitigation measures: } \\
>\quad \text { Mitigation actions. } \\
\text { Additional analysis- } \\
\text { capacity analysis. } \\
>\text { Optional mitigation. } \\
>\text { Quantification of cost } \\
\text { implications. } \\
>\text { On-site improvements. } \\
>\text { Off-site improvements. } \\
>\text { Fair-share mitigation } \\
\text { - Trip reduction measures. } \\
\text { - Other analysis to be } \\
\text { included: } \\
>\text { Stopping sight distance } \\
\quad \text { analysis and } \\
\text { measurements } \\
\text { Parking analysis }\end{array}$ \\
\hline
\end{tabular}

Source: Own construction from sources as indicated, 2012.

Traffic impact assessment/studies internationally are fundamental as part of the EIA process as a specialist report in activity authorization. The components of the TIAs can be considered as minimum standards [19]. These elements will support the EIA in authorization to evaluate the overall impacts of a project. It will thus enhance sustainable development through the implementation of mitigation measures related to traffic and transportation impacts.

\section{Case study content, approach and application}

The following TIS/TIA content, approach and application (Table 2) was followed in the case study as reported on in paper [20].

If the content of Tables 1 and 2 is compared, it is evident that although it is possible to have a manual or format on the content for TIS/TIA formulation, the focus and needs for such research differs from one project to the next and from one site to the next. This implies that the research design should be developed by the TIS/TIA practitioner in cooperation with other specialists based on specific project reality and needs.

From the perspective of EIA and TIS/TIA integration, the research design should also be informed by the environmental assessment practitioner (EAP). Input into the TIS/TIA research design by civil engineers, sociologists, economist, urban and regional planners, transportation economists and air quality scientists should be considered as a non-negotiable requirement. On completion the TIS/TIA research design should be submitted to all stakeholders and affected parties for input and information. 
Table 2: TIA content, approach and application related to the case study, 2011.

\begin{tabular}{|c|c|c|}
\hline $\begin{array}{l}\text { Research } \\
\text { focus }\end{array}$ & Content description & Objective/purpose \\
\hline Task 1 & $\begin{array}{l}\text { - Project approach: } \\
>\text { Research design. } \\
>\text { Assessment of existing knowledge. }\end{array}$ & $\begin{array}{l}\text { - Research concept } \\
\text { development. } \\
\text { - Status quo } \\
\text { assessment. }\end{array}$ \\
\hline Task 2 & - Locational assessment of study area & - Regional context \\
\hline Task 3 & - Formulation of research goals and objectives & - Research delimitation \\
\hline Task 4 & $\begin{array}{l}\text { - Analysis of the status quo transportation and traffic } \\
\text { analysis } \\
>\text { Socio economic profile } \\
>\text { Transportation profile } \\
>\text { Traffic distribution patterns }\end{array}$ & $\begin{array}{l}\text { - Socio-economic } \\
\text { reality } \\
\text { - Traffic assessment } \\
\text { and generation }\end{array}$ \\
\hline Task 5 & • Environmental reality. & - Alignment and impact \\
\hline Task 6 & - Land use and development perspective & $\begin{array}{l}\text { - Regional alignment } \\
\text { assessment }\end{array}$ \\
\hline Task 7 & $\begin{array}{l}\text { Quantification of traffic flow impacts } \\
>\text { Existing and projected traffic flows } \\
>\text { Traffic flows due to proposed activities } \\
>\text { Management of traffic demand } \\
>\text { Impacts on road network accommodating form } \\
\text { intra- and inter traffic perspective }\end{array}$ & - Impact quantification \\
\hline Task 7 & $\begin{array}{l}\text { - Land use and transportation integration } \\
>\quad \text { Spatial Development Framework (SDF) } \\
>\quad \text { Integrated Transport Plan (ITP) } \\
>\quad \text { Statutory planning and land use impacts }\end{array}$ & $\begin{array}{l}\text { - Alignment and } \\
\text { integration } \\
\text { - Coordination } \\
\text { - Articulation }\end{array}$ \\
\hline Task 8 & $\begin{array}{l}\text { - Future traffic flow determinants and growth patterns } \\
\text { related to off-site impacts }\end{array}$ & $\begin{array}{l}\text { - Impact assessment } \\
\text { - Projections } \\
\text { - Quantification }\end{array}$ \\
\hline Task 9 & $\begin{array}{l}\text { - Trip generation and assignment of on-site traffic } \\
\text { - Site access analysis }\end{array}$ & $\begin{array}{l}\text { - Site development } \\
\text { impacts } \\
\text { - Traffic movement } \\
\text { patterns } \\
\end{array}$ \\
\hline Task 10 & $\begin{array}{l}\text { Transport infrastructure improvements off-site } \\
>\text { Geometric design standards and improvements } \\
>\text { Structural design considerations } \\
>\text { Road network improvements } \\
>\text { Illumination upgrading } \\
>\text { Pedestrian lanes provision } \\
>\text { Infrastructure upgrading project scheduling }\end{array}$ & $\begin{array}{l}\text { - Infrastructure } \\
\text { upgrading } \\
\text { - Traffic mitigation } \\
\text { - Project integration } \\
\text { - Traffic mode } \\
\text { separation } \\
\text { - Safety and security }\end{array}$ \\
\hline Task 11 & $\begin{array}{l}\text { - Transport and traffic infrastructure on-site } \\
\text { improvements } \\
>\text { Provision of additional parking } \\
>\text { Improvement of loading and off-loading } \\
\text { facilities } \\
>\text { Improvement of operational measures and } \\
\text { arrangements } \\
>\text { Provision of holding areas for heavy motor } \\
\text { vehicles } \\
>\text { Improvement of accessibility to site }\end{array}$ & $\begin{array}{l}\text { - Safety and security } \\
\text { - Improvement of } \\
\text { traffic flow } \\
\text { - Addressing of } \\
\text { transport and traffic } \\
\text { backlogs } \\
\text { - Improved site } \\
\text { management }\end{array}$ \\
\hline
\end{tabular}


Table 2: $\quad$ Continued.

\begin{tabular}{|c|c|c|}
\hline $\begin{array}{l}\text { Research } \\
\text { focus }\end{array}$ & Content description & Objective/purpose \\
\hline Task 12 & $\begin{array}{l}\text { - Formulation of a transport and traffic mitigation goal } \\
\text { achievement matrix (TTMGAM) }\end{array}$ & $\begin{array}{l}\text { - } \text { Coordination and } \\
\text { project integration } \\
\text { - Application of } \\
\text { performance } \\
\text { indicators } \\
\text { - Action plan }\end{array}$ \\
\hline Task 13 & - Project conclusions & $\begin{array}{l}\text { - Research goal and } \\
\text { objective realization }\end{array}$ \\
\hline
\end{tabular}

Source: Own construction, 2012.

\section{Overview of the case study}

\subsection{Description of site}

The TIS/TIA research is based on an existing industrial development site that is accommodating mineral processing plant and associated infrastructure in South Africa [20]. The study area forms part of the Kgangala District Municipality (GDM).

The TIS/TIA research was carried out as a specialist report for the EIA process for authorization in terms of the EIA Regulations [7] for the extension of an existing plant facility. The plant imports all of its mineral resources by road whilst the production is being transported by rail from the site. For the purposes of this paper, the approach followed will only be reported on from a generic perspective only as the EIA authorization is still in process.

\subsection{Research goal formulation}

The goal of the TIS/TIA for the study area is to assess the status quo position of transportation and traffic related matters in context to the present extend of core activities. This is used as a norm to determine the traffic impact of the future extended activities. Based on this determination applicable mitigation measures were recommended. The following specific objectives in goal realization are applicable:

- $\quad$ Objective 1: Analysis of the status quo transportation and traffic reality applicable to the site.

- $\quad$ Objective 2: Quantification of the traffic flow and facility impacts based on the proposed extended core activities.

- $\quad$ Objective 3: Optimization of land use, traffic and environmental relationships and impacts.

- $\quad$ Objective 4: Inter- and intra traffic movement integration and optimization. 
- $\quad$ Objective 5: Formulation of transportation and traffic mitigation measures based on goal achievement through specific related projects.

- $\quad$ Objective 6: Implementation planning.

\subsection{Summary of the traffic assessment results}

Both the inter traffic and intra traffic movements were taken up consisting of a modal split between private motor vehicles (PMV), light delivery vans (LDV), busses (B), minibus taxis (MBT); heavy motor vehicles (HMV) and pedestrians. Figure 1 shows the traffic survey sites within the road network and intersections.

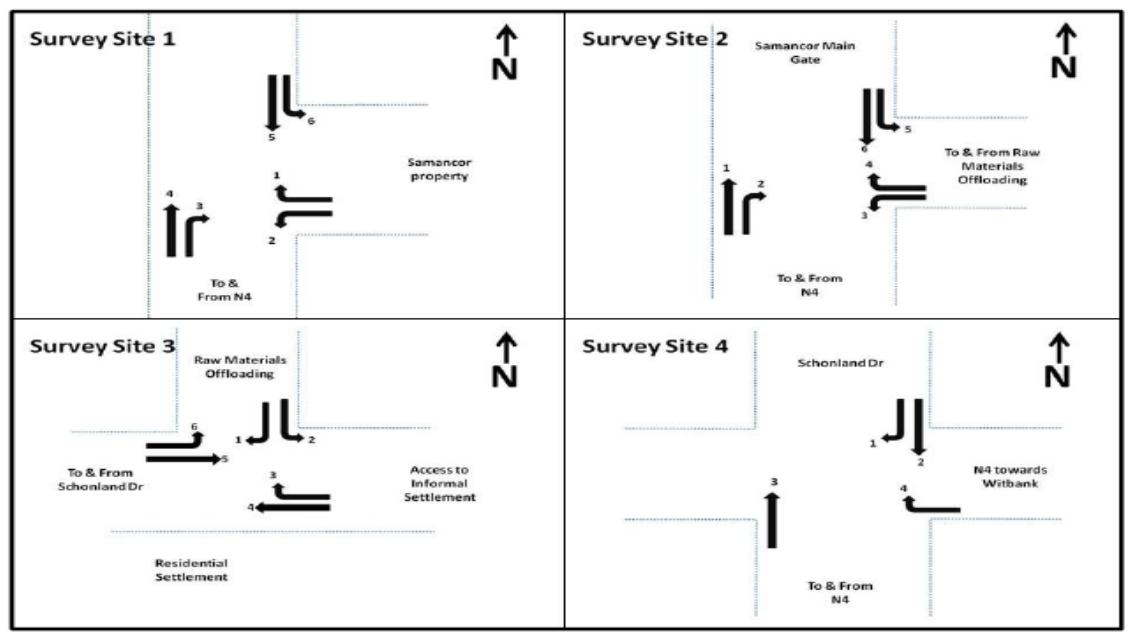

Figure 1: $\quad$ Traffic flow directions surveyed.

The traffic survey included in terms of modal split peak and off-peak counts for each of the survey points. The total traffic survey summary is contained in Table 3. Figures 2 and 3 show the graphical presentation of the traffic data. Table 3 clearly depicts that the daily traffic movements within the study area amounts to 18390 movements of which some 3822 are related to non-motorized traffic. Some 14669 represents motorized traffic. Private motor vehicles (PMV) represent 8075 movements (55.42\%); Heavy Motor Vehicles (HMV) represents the figure of 2,950 (20.24\%) of the total motorized traffic movements. As far as passenger transport is concerned, 1550 minibus-taxis (10.36\%) and bus transport some $4.07 \%$ of all motorized traffic movements.

The peak hour and off-peak hour traffic within the inter-traffic movement patterns are also captured in Table 3. From an analysis of the survey data the peak and off-peak traffic patterns show clear clustering patterns. Some $74.01 \%$ of all traffic movements relates to peak hour traffic occurrence [20].

From the perspective of this TIS/TIA, the traffic flow patterns related to nonmotorized traffic is of significance: some $20.78 \%$ of all traffic movements relates 
Table 3: $\quad$ Total traffic counts within the study area.

\begin{tabular}{|c|c|c|c|c|c|c|c|c|c|c|c|}
\hline \multirow{4}{*}{ 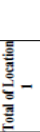 } & Traffic characteristic & PMV & LDV & Taxis & HMV & Busses & $\begin{array}{l}\text { Total: } \\
\text { Motorised } \\
\text { Traffic }\end{array}$ & Pedestrians & Bicycles & $\begin{array}{l}\text { Total: Non- } \\
\text { motorised } \\
\text { Traffic }\end{array}$ & \\
\hline & Total peak hour traffic & 570 & 147 & 73 & 361 & & & & & & 1797 \\
\hline & Total: Off peak Traffic & 241 & 56 & 33 & 85 & 18 & 433 & 181 & 9 & 190 & 621 \\
\hline & Total traffic: All movements & 811 & 203 & 106 & 446 & 77 & 1643 & 756 & 21 & 777 & 2420 \\
\hline \multirow{3}{*}{ 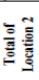 } & Total peak hour traffic & 1714 & 343 & 209 & 938 & 86 & 3290 & 1602 & 79 & 1681 & 4971 \\
\hline & Total: Off peak Traffic & 580 & 129 & 62 & 318 & 28 & 1117 & 479 & 19 & 498 & 1648 \\
\hline & Total traffic: All movements & 2294 & 472 & 271 & 1256 & 114 & 4407 & 2081 & 98 & 2179 & 6619 \\
\hline \multirow{4}{*}{ 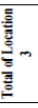 } & & & & & & & & & & & \\
\hline & Total peak hour traffic & 116 & 13 & 7 & 95 & 1 & 232 & 434 & 43 & 477 & 709 \\
\hline & Total: Off peak Traffic & 56 & 18 & 7 & 46 & 0 & 127 & 128 & 21 & 149 & 322 \\
\hline & Total traffic: All movements & 171 & 31 & 14 & 141 & 1 & 359 & 562 & 64 & 626 & 1031 \\
\hline \multirow{3}{*}{ 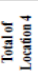 } & Total peak hour traffic & 3582 & 451 & 887 & 807 & 323 & 6050 & 110 & 26 & 136 & 6186 \\
\hline & Total: Off peak Traffic & 1216 & 242 & 272 & 300 & 79 & 2109 & 80 & 24 & 104 & 2213 \\
\hline & Total traffic: All movements & 4798 & 693 & 1159 & 1107 & 402 & 8159 & 190 & 50 & 240 & 8399 \\
\hline \multirow{3}{*}{ 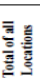 } & Total peak hour traffic & 5982 & 954 & 1176 & 2201 & 469 & 10782 & 2721 & 160 & 2881 & 13663 \\
\hline & Total: Off peak Traffic & 2093 & 445 & 374 & 749 & 125 & 3786 & 868 & 73 & 941 & 4804 \\
\hline & Total traffic: All movements & 8075 & 1399 & 1550 & 2950 & 594 & 14568 & 3589 & 233 & 3822 & 18390 \\
\hline
\end{tabular}

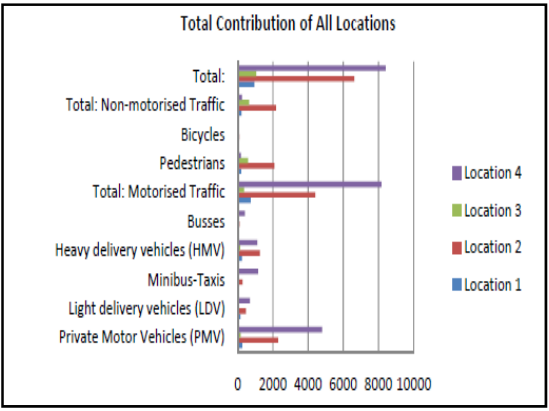

Figure 2: Total contribution of traffic.

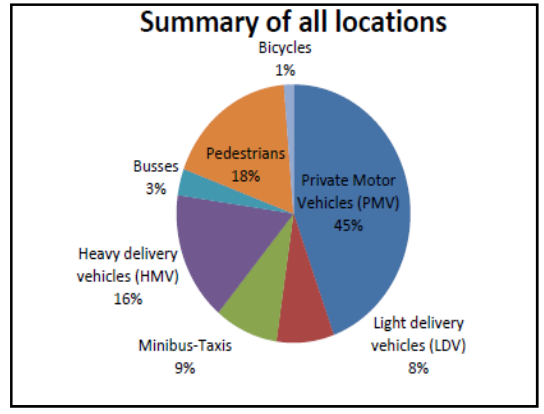

Figure 3: $\quad$ Summary of traffic.

to pedestrians and bicycle movements. From the survey the lack of adequate infrastructure (cycle and pedestrian lanes) to accommodate such modes of transport can be deduced [20].

\section{Mitigation and intervention strategy}

The following transport related topics are being dealt with extensively: inter traffic movement; access movements onto the site; and on-site traffic movements. Based on the TIS/TIA research output it is possible to assess the traffic flow impacts on the road network supported by an in depth analysis of the intra-traffic growth model based on a scenario approach within a five (5) year time horizon [20].

In the source document transportation and land use integration based on the impact of the proposed site development is aligned with SDFs for the local 
sphere of government (municipalities). No ITP for the study area exists that served as an important motivation for the TIS/TIA formulation. Traffic flow determinants and growth trends related to the development of the site and its associated greater region is also included in the TIS/TIA.

The road network serving the site is assessed from both a geometric as well as structural road design standards as to determine the status quo position. Specific mitigation measures for road network upgrading are proposed [20]. Various alternatives for transportation and traffic related improvements (infrastructure) in the light of the required mitigation measures to ensure sustainable development are made. A detailed budget for road upgrading; identified project components; implementation framework; estimated cost; source of possible funding and mitigation objectives are identified.

\section{Transportation and traffic mitigation goal achievement matrix (TTGAM)}

Following the mitigation and intervention strategy focus (as described in point 6 above) a coordination and implementation assessment framework (Table 4) (TTMGAM) based on the outcomes of the TIS/TIA is applied. This framework is used to rank the projects, focuses, measures and projects as identified above.

Table 4: Transportation and Traffic Mitigation Goal Achievement Matrix (TTMGAM).

\begin{tabular}{|l|l|l|l|}
\hline \multirow{2}{*}{$\begin{array}{l}\text { Transport and Traffic } \\
\text { Fundamental (TTF) }\end{array}$} & \multicolumn{3}{|c|}{ Score/Weight } \\
\cline { 2 - 4 } $\begin{array}{l}\text { 1: Effective and efficient } \\
\text { upgrading and } \\
\text { development of improved } \\
\text { accessibility to the site by } \\
\text { road }\end{array}$ & $\begin{array}{l}\text { Maintaining } \\
\text { status quo }\end{array}$ & $\begin{array}{l}\text { Ensure a moderate } \\
\text { improvement (crisis } \\
\text { management) }\end{array}$ & $\begin{array}{l}\text { Enable plant to fulfil its } \\
\text { production targets. }\end{array}$ \\
\hline $\begin{array}{l}\text { 2: Implementation of } \\
\text { improved traffic safety } \\
\text { measures }\end{array}$ & $\begin{array}{l}\text { Maintaining } \\
\text { status quo }\end{array}$ & $\begin{array}{l}\text { Provide a limited } \\
\text { improvement in traffic } \\
\text { safety needs and } \\
\text { requirements }\end{array}$ & $\begin{array}{l}\text { Will contribute largely } \\
\text { to the improved safe } \\
\text { access and intra-traffic } \\
\text { movement }\end{array}$ \\
\hline $\begin{array}{l}\text { 3: The protection of } \\
\text { environmentally sensitive } \\
\text { areas, adjacent land uses to } \\
\text { support environmental } \\
\text { sustainability within the } \\
\text { area }\end{array}$ & $\begin{array}{l}\text { Maintaining } \\
\text { status quo }\end{array}$ & $\begin{array}{l}\text { Provide limited } \\
\text { improvement in } \\
\text { protection, } \\
\text { development and } \\
\text { enhancement of the } \\
\text { environment. }\end{array}$ & $\begin{array}{l}\text { Will contribute } \\
\text { extensively to the } \\
\text { protection and } \\
\text { enhancement of the } \\
\text { environment. }\end{array}$ \\
\hline $\begin{array}{l}\text { 4: Actively address storm } \\
\text { water runoff from the site. }\end{array}$ & $\begin{array}{l}\text { Maintaining } \\
\text { status quo }\end{array}$ & $\begin{array}{l}\text { Will to some extend } \\
\text { curtail storm water } \\
\text { runoff. No provision } \\
\text { within the access } \\
\text { upgrading }\end{array}$ & $\begin{array}{l}\text { Will greatly contribute } \\
\text { to the elimination of } \\
\text { polluted runoff from the } \\
\text { site. }\end{array}$ \\
\hline $\begin{array}{l}\text { 5: Improvement of on-site } \\
\text { operation practices and } \\
\text { facilities }\end{array}$ & $\begin{array}{l}\text { Maintaining } \\
\text { status quo }\end{array}$ & $\begin{array}{l}\text { Will to some extend } \\
\text { improve some of the } \\
\text { on-site operational } \\
\text { practices and facilities }\end{array}$ & $\begin{array}{l}\text { Will implement and /or } \\
\text { facilitate all of the } \\
\text { recommended } \\
\text { operational practices. }\end{array}$ \\
\hline
\end{tabular}


Each project as mentioned in point 6 is adjudicated in terms of how well it contributes to the set transportation and traffic fundamentals (TTF) (Table 4). The sum total of its contribution is viewed as its conformation weight and is referred to as the Transportation and Traffic Mitigation Goal Achievement Score (TTMGAM Score). Projects should be implemented based on its ranking in terms of its score assessment score.

Table 5 shows the outcome of the transportation and traffic mitigation measures (direct and indirect) as identified for the activities addressed in the TIS/TIA. From the table the priority of the transportation and traffic mitigation measures in terms of priority can be deduced.

Table 5: Transportation and traffic mitigation goal achievement in study area.

\begin{tabular}{|c|c|c|c|c|c|c|c|c|c|}
\hline \multirow[t]{2}{*}{ Activity } & \multicolumn{6}{|c|}{$\begin{array}{c}\text { TTMGAM Score based } \\
\text { on TTF }\end{array}$} & \multirow[t]{2}{*}{ Status quo position } & \multirow[t]{2}{*}{ Objective } & \multirow[t]{2}{*}{$\mathbf{P}$} \\
\hline & 1 & 2 & 3 & 4 & 5 & $T$ & & & \\
\hline $\begin{array}{l}\text { Upgrading of } \\
\text { the N/South } \\
\text { access road }\end{array}$ & 3 & 3 & 5 & 3 & 1 & 15 & $\begin{array}{l}\text { Present road in poor } \\
\text { condition. Increase } \\
\text { in traffic flow. }\end{array}$ & $\begin{array}{l}\text { Improved } \\
\text { geometric and } \\
\text { structural design. }\end{array}$ & 5 \\
\hline $\begin{array}{l}\text { Formalization } \\
\text { of the West/East } \\
\text { access road }\end{array}$ & 5 & 3 & 3 & 3 & 3 & 17 & $\begin{array}{l}\text { Ownership of access } \\
\text { road undetermined. }\end{array}$ & $\begin{array}{l}\text { Formal } \\
\text { proclamation and } \\
\text { construction. }\end{array}$ & 3 \\
\hline $\begin{array}{l}\text { Storm water } \\
\text { management } \\
\text { strategy }\end{array}$ & 1 & 1 & 5 & 5 & 5 & 17 & $\begin{array}{l}\text { No formal strategy } \\
\text { exists. }\end{array}$ & $\begin{array}{l}\text { Applicable design } \\
\text { of storm water } \\
\text { measures. }\end{array}$ & 3 \\
\hline $\begin{array}{l}\text { Upgrading } \\
\text { loading } \\
\text { facilities }\end{array}$ & 5 & 3 & 5 & 5 & 5 & 23 & $\begin{array}{l}\text { Dedicated off- } \\
\text { loading and loading } \\
\text { facilities exist. }\end{array}$ & $\begin{array}{l}\text { Upgrading of } \\
\text { facility. }\end{array}$ & 1 \\
\hline $\begin{array}{l}\text { Protection of } \\
\text { the adjacent } \\
\text { land uses }\end{array}$ & 3 & 3 & 3 & 3 & 5 & 17 & $\begin{array}{l}\text { Residential } \\
\text { informality } \\
\text { problematic. }\end{array}$ & $\begin{array}{l}\text { Formalization } \\
\text { required. }\end{array}$ & 3 \\
\hline $\begin{array}{l}\text { Promotion of } \\
\text { traffic safety }\end{array}$ & 5 & 5 & 1 & 1 & 5 & 16 & Pedestrians at risk. & $\begin{array}{l}\text { Improved } \\
\text { geometric design } \\
\text { standards }\end{array}$ & 4 \\
\hline $\begin{array}{l}\text { Improved } \\
\text { accessibility }\end{array}$ & 5 & 5 & 3 & 3 & 1 & 17 & $\begin{array}{l}\text { Accessibility is } \\
\text { problematic. }\end{array}$ & $\begin{array}{l}\text { Access } \\
\text { formalization and } \\
\text { upgrading. }\end{array}$ & 3 \\
\hline $\begin{array}{l}\text { Protection of } \\
\text { the environment }\end{array}$ & 5 & 3 & 5 & 3 & 3 & 19 & $\begin{array}{l}\text { IEM approach is } \\
\text { lacking. }\end{array}$ & $\begin{array}{l}\text { Environmental } \\
\text { management } \\
\text { practices. }\end{array}$ & 2 \\
\hline $\begin{array}{l}\text { Promotion of } \\
\text { community. }\end{array}$ & 3 & 5 & 3 & 5 & 1 & 17 & $\begin{array}{l}\text { Informality creates } \\
\text { lack of structure. }\end{array}$ & Formalization. & 3 \\
\hline
\end{tabular}

\section{Conclusion}

From the contents of the paper it was illustrated that TIS/TIAs fulfils an important role in EIA adjudication with regard to environmental authorization for development activities. It was also illustrated that the contents of TIS/TIAs to be designed based on trans-disciplinary consultation processes and specific research and site needs. The application of goal achievement tools in project 
prioritization for the implementation to address mitigation from a traffic as well as transportation perspective is a basic need to support sustainable planning and development.

\section{References}

[1] Republic of South Africa: National Environmental Management Act (Act 73 of 1989). Pretoria. Government Printer, (1989).

[2] Sowman, R. Fuggle, R. and Preston, G.: A review of the evolution of environmental evaluation procedures in South Africa. Environmental Impact Review, No.15, (1995).

[3] Council for the Environment: Integrated Environmental Management in South Africa. Pretoria. Joan Lotter Publications, (1989).

[4] Republic of South Africa: National Environmental Management Act (Act 107 of 1998). Pretoria. Government Printer, (1998).

[5] DEAT: Overview of Integrated Environmental Management, Integrated Environmental Management, Information Series 0, Department of Environmental Affairs and Tourism (DEAT). Pretoria, (2004).

[6] Republic of South Africa: Regulations in terms of Chapter 5 of the National Environmental Management Act, 1998. Regulation R.385. Pretoria. Government Printer, (2006).

[7] Republic of South Africa: Regulations in terms of Chapter 5 of the National Environmental Management Act, 1998. Regulations R.543 to R.547). Pretoria. Government Printer, (2010).

[8] Republic of South Africa: National Land Transport Act (Act 5 of 2009). Pretoria. Government Printer, (2009).

[9] Republic of South Africa: R. 1208 National Land Transport Act (5/2009): National Land Transport Regulations. Pretoria. Government Printer, (2009) Republic of South Africa: R. 877 National Land Transport Act (5/2009): National Land Transport Regulations on Contracting for Public Transport Services. Pretoria. Government Printer, (2009).

[10] Department of Transport (1995): RR 93/635 Manual for traffic impact studies. Pretoria. Government Printer and NDOT.

[11] Committee of Transport Officials (2008): Traffic Impact and Site Assessments. Unpublished.

[12] DEAT: Overview of Integrated Environmental Management, Integrated Environmental Management, Information Series 0, Department of Environmental Affairs and Tourism (DEAT). Pretoria, (2004).

[13] DEAT: Information Series 4: Specialist Studies, Department of Environmental Affairs and Tourism (DEAT). Pretoria, (2004).

[14] DEAT: Information Series 5: Impact Significance, Department of Environmental Affairs and Tourism (DEAT). Pretoria, (2004).

[15] DEAT: Information Series 7: Cumulative Effects Assessment, Department of Environmental Affairs and Tourism (DEAT). Pretoria, (2004). 
[16] DEAT: Information Series 13: Review of Environmental Impact Assessment, Department of Environmental Affairs and Tourism (DEAT). Pretoria, (2004).

[17] Asia Society for Transportation Studies: Vol. 5, pp.2342-2351, (2005).

[18] Alberta Infrastructure and Transportation Traffic Impact Assessment Guideline. Prepared by Stantec Consulting Ltd, (2005).

[19] Cape Cod Commission: Cape Cod Commission Guidelines for Transportation Impact Assessment. Barnstable, (2003).

[20] ETAPLANNING cc: Research and traffic surveys undertaken for the extension of a mineral processing plant, (2011). 